\title{
ANALISIS KEPUASAN KONSUMEN TERHADAP TEMBAKAU RAKYAT “KASTURI" DI KECAMATAN PRINGGASELA KABUPATEN LOMBOK TIMUR
}

\section{ANALYSIS OF CONSUMER SATISFACTION WITH TOBACCO "KASTURI" IN PRINGGASELA DISTRICT EAST LOMBOK REGENCY}

\author{
Linda Rusiani $^{1 *}$, Tajidan $^{2}$, Rosmilawati $^{2}$ \\ ${ }^{1 * 2,2}$ Program Studi Agribisnis, Universitas Mataram, Mataram, Indonesia \\ *Email Penulis korespondensi: rusianilinda9@gmail.com
}

\begin{abstract}
ABSTRAK
Penelitian ini bertujuan untuk: 1) Untuk mengetahui atribut-atribut tembakau rakyat "Kasturi" yang mempengaruhi kepuasan konsumen dalam membeli tembakau rakyat "Kasturi" di Kecamatan Pringgasela, 2) Untuk mengetahui atribut-atribut tembakau rakyat "Kasturi" yang perlu untuk diperbaiki guna meningkatkan kepuasan konsumen tembakau rakyat "Kasturi" di Kecamatan Pringgasela, 3) Untuk mengetahui tingkat kepuasan konsumen dalam mengkonsumsi tembakau rakyat "Kasturi" di Kecamatan Pringgasela. Metode yang digunakan dalam penelitian ini adalah metode deskriptif dan teknik pengumpulan data menggunakan angket/kuesioner dan observasi. Penelitian ini dilakukan di Kecamatan Pringgasela. Penentuan responden ditetapkan sebanyak 70 responden, jenis data yang digunakan adalah data kuantitatif dan kualitatif, sedangkan sumber data yang digunakan adalah data primer dan sekunder. Data yang diperoleh dianalisis dengan cara: 1) Uji Validitas dan Reliabilitas, 2) Uji Importance Performance Analysis (IPA) dan 3) Uji Customer Statisfaction Index (CSI). Hasil penelitian menunjukkan bahwa 1) Atribut-atribut produk yang menentukan kepuasan konsumen terdapat pada kuadran II meliputi 5 atribut, 2) Atribut-atribut produk yang perlu untuk diperbaiki guna meningkatkan kepuasan konsumen tembakau rakyat "kasturi" terdapat pada kuadran I dan III meliputi 5 atribut, 3) Tingkat kepuasan konsumen terhadap tembakau rakyat "kasturi" di Kecamatan Pringgasela menunjukkan bahwa secara keseluruhan konsumen merasa sangat puas terhadap tembakau rakyat "kasturi", hal ini dapat dilihat dari nilai CSI sebesar 76,43\% dengan rentang skala $75-100 \%$.
\end{abstract}

Kata-Kata Kunci: Kepuasan Konsumen, CSI, IPA, Tembakau Rakyat

\begin{abstract}
This study aims to: 1) find out the attributes of the people's tobacco "kasturi" which affect consumer satisfaction in buying people's tobacco "kasturi" in Pringgasela District. 2) find out the attributes of "kasturi" people's tobacco that need to be improved in order to improve satisfaction of the people's tobacco "kasturi" consumers in Pringgasela District. 3) determine the level of consumer satisfaction in consuming "kasturi" people's tobacco in Pringgasela District. The method used in this research is descriptive method and data collection techniques using a questionnaire and observation. This research was conducted in Pringgasela District. The determination of respondents was determined as many as 70 respondents, the types of data used were quantitative and qualitative data, while the data source used are primary and secondary data. The data obtained were analyzed by: 1) validity and Reliability Test, 2) Importance Performance Analysis (IPA) Test dan 3) Customer Statisfaction Index (CSI) Test. The results showed that: 1). The product attributes that determine customer satisfaction are found in quadrant II including 5 attributes, 2). Product attributes that need to be improved in order to increase the satisfaction of consumers of the "kasturi" traditional tobacco are found in quadrants I and III covering 5 attributes, 3). The level of consumer satisfaction with "kasturi" traditional tobacco in Pringgasela District shows that overall consumers feel very satisfied with people's tobacco "kasturi" traditional tobacco, this can be seen from the CSI value of $76,43 \%$ with a scale range of $75-100 \%$.
\end{abstract}

Keywords: Consumers satisfaction, CSI, IPA, people's tobacco

Rusiani, L., Tajidan, dan Rosmilawati. 


\section{PENDAHULUAN}

Tembakau termasuk salah satu komoditas perkebunan yang mempunyai arti penting karena memberikan manfaat ekonomi dan sosial. Komoditas tembakau dari segi ekonomis mampu memberikan sumbangan yang cukup besar bagi pendapatan negara dan penciptaan lapangan kerja (Wilujeng, 2003). Peran tembakau didalam prekonomian Indonesia dapat ditunjukkan oleh besarnya cukai dan devisa ekspor yang disumbangkan sebagai penerimaan negara (Rachmat, 2010). Salah satunya tembakau digunakan sebagai bahan baku rokok dan cerutu. Perkembangan tembakau di Indonesia tidak bisa terlepas dari keberadaan industri, peran tembakau dalam prekonomian nasional dapat dilihat dari beberapa indikator seperti peranannya dalam penerimaan negara (PDB). Salah satu sentra tembakau di Indonesia yang memiliki nilai jual tinggi ialah di Nusa Tenggara Barat (NTB).

Tembakau di Nusa Tenggara Barat merupakan salah satu komoditas perkebunan dengan luas lahan penanaman yang cukup besar yaitu 35,14 Ha pada tahun 2019 (BPS NTB, 2020).Tembakau di Nusa Tenggara Barat memiliki nilai jual yang tinggi sehingga dapat meningkatkan prekonomian masyarakat setempat. Ada dua jenis tembakau yang dikembangkan di Nusa Tenggara Barat yaitu tembakau rakyat atau biasa dikenal dengan tembakau rajangan dan tembakau virginia. Tembakau rajangan merupakan tembakau yang diolah secara manual/tradisional dan banyak dijadikan usaha oleh petani di Nusa Tenggara Barat terutama yang ada di Kabupaten Lombok Timur.

Sudah lumrah jika kita dapati orang-orang di Lombok memilih tembakau rajangan dengan selembar atau dua lembar kertas rokok saat istirahat dari bekerja. Asap akan mengepul dan menebarkan aroma khas saat duduk berkumpul, saat bekerja di sawah atau di kebun, atau di mana saja, biasanya mereka menjepit sebatang rokok lintingan (tembakau rajangan). Kemana-mana mereka selalu membawa segenggam tembakau dengan dompet bekas perhiasan ataupun kresek kecil yang dilengkapi kertas rokok dan korek api. Berbeda dengan tembakau Virginia, proses pengolahannya terlebih dahulu dikeringkan dengan oven sebelum dijual ke perusahaan rokok dalam bentuk daun kering atau disebut krosok.

Produktivitas dan harga tembakau Virginia di pasaran tergolong lebih tinggi jika dibandingkan dengan tembakau rakyat (Nursan, dkk., 2020). Seiring naiknya harga rokok putih olahan pabrik seperti Gudang Garam, Sampoerna, Malrboro dan lain lain, kini penikmat rokok lintingan atau rokok dari tembakau rajangan meluas pangsa pasarnya mulai dari usia muda hingga para orang tua yang sebelumnya anak muda biasanya gengsi untuk merokok tembakau rajangan. Melihat semakin besarnya peminat rokok tembakau rajangan menjadi peluang besar bagi para petani tembakau dan produsen tembakau rajangan untuk mengolah tembakau rajangan menjadi produk yang siap di pasarkan secara luas. Umumnya tembakau rajangan dijual dalam bentuk tumpi dan bal (satu bal terdiri atas 18 sampai 20 tumpi) dengan harga yang bervariasi tergantung jenis tembakaunya mulai dari Rp.35.000 - Rp.500.000 per tumpi dan yang termahal adalah tembakau jenis senang. Maka dari itu untuk menjangkau konsumen yang lebih luas, para produsen saat ini menjual dalam bentuk eceran kemasan plastik yang dijual dengan harga Rp.5000 per kemasan dan diecer ke warung-warung atau kios-kios kecil di masyarakat. Salah satu daerah penyebaran tembakau rakyat "kasturi" adalah Kecamatan Pringgasela.

Melihat semakin menjamurnya peredaran tembakau rajangan yang dijual secara eceran ini menimbulkan perhatian dari pemerintah. Hal ini dikarenakan banyaknya produsen tembakau rajangan yang menjual tanpa izin dan tanpa pita cukai. Selain itu 
kualitas dari tembakau ini belum diketahui pasti apakah dicampur zat kimia atau tidak. Ada berbagai macam merek yang beredar di masyarkat hususnya dari pengamatan peneliti yang berada di kecamatan Pringgasela antara lain merek selingkuh, janda, harum manis, dan mawar, yang sebagian besar di produksi dari wilayah kecamatan Masbagik.

Secara khusus penelitian ini bertujuan untuk: (1) menganalisa atribut-atribut yang mempengaruhi tingkat kepuasan konsumen; (2) menganalisa atribut-atribut yang menjadi prioritas utama dalam perbaikan kualitas produk olahan tembaku rajangan yang beredar di Kecamatan Pringgasela; dan (3) menganalisa tingkat kepuasan konsumen terhadap kualitas produk tembakau rakyat "kasturi" di Kecamatan Pringgasela.

\section{METODE PENELITIAN}

Metode yang digunakan dalam penelitian ini adalah metode Kualitatif, sedangkan pengumpulan data dilakukan dengan menggunakan kuesioner, wawancara semi struktur dan observasi langsung. Jumlah responden ditentukan menggunakan metode Probability Sampling dan Covinience Sampling. Kemudian ditentukan sebanyak 70 orang responden menggunakan uji kecukupan data.

Jenis data yang digunakan dalam penelitian ini adalah data kuantitatif dan data kualitatif. Data-data yang digunakan dalam penelitian ini terdiri dari dua sumber, yaitu: (1) Data Primer, berupa hasil jawaban kuisioner yang diisi oleh responden tentang produk, harga, kemasan, performansi, dan khasiat; (2) Data Sekunder, berupa laporan yang dipublikasikan ataupun tidak dipublikasikan yang berhubungan dengan penelitian yang dilakukan, data-data dari Badan Pusat Statistik (BPS), Unit Pelaksana Tekhnik Penyuluhan Pertanian (UPT PP), Kantor desa dan Dinas Pertanian Lombok Timur.

Analisa atribut-atribut yang mempengaruhi kepuasan konsumen dan atribut-atribut yang perlu untuk diperbaiki guna meingkatkan kepuasan konsumen menggunakan Uji Importance Performance Analysis (IPA), yaitu terdiri dari beberapa tahap (Supranto dalam Santoso, 2011):

1. Menghitung tingkat kesesuaian untuk setiap atribut yang dipersepsikan oleh konsmen, dengan rumus:

Tingkat Kesesuaian $=\frac{\sum_{i=1}^{n} X i}{\sum_{i=1}^{n} Y i} \times 100 \%$

Keterangan:

$\mathrm{X}$ : Skor tingkat kinerja pada setiap atribut

$\mathrm{Y}$ : Skor tingkat kepentingan pada setiap atribut

$\mathrm{N}$ : Jumlah responden

I : Responden ke-i

2. Menghitung rata-rata seluruh atribut tingkat kepentingan (Y) dan kinerja (X) yang menjadi batas dalam diagram kartesius, dengan rumus sebagai berikut:

$a=\frac{\Sigma X I}{k}$ dan $b=\frac{\Sigma Y I}{k}$

Keterangan :

a : Batas sumbu $X$ (tingkat kinerja)

$\mathrm{b}$ : Batas sumbu Y (tingkat kepentingan)

$\mathrm{k}$ : Banyak variabel yang diteliti

Rusiani, L., Tajidan, dan Rosmilawati. 
3. Penjabaran tiap atribut dalam diagram kartesius seperti pada Gambar 1 berikut:

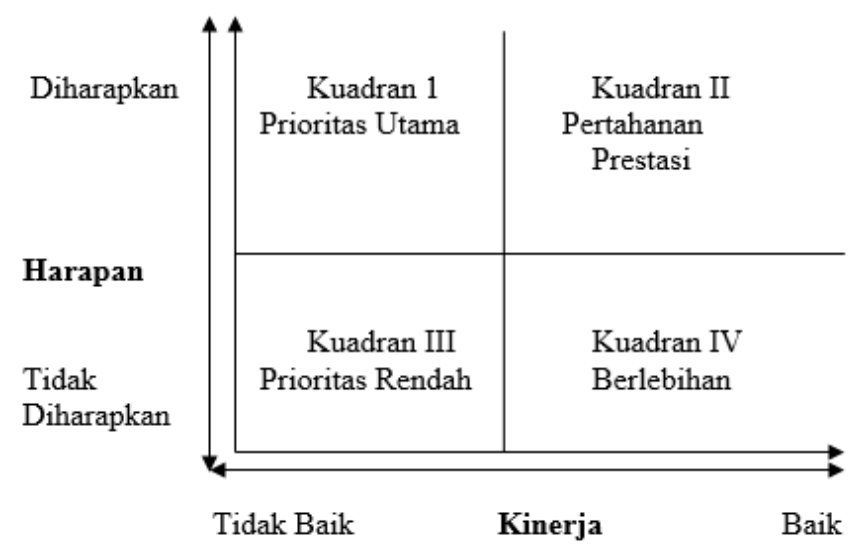

Sumber: Priagus (2019)

Gambar 1. Diagram Kartesius Importance Performance Analysis (IPA) dari:

Setiap hasil akan menempati salah satu kuadran dalam diagram kartesius yang terdiri

1) Kuadran I (Prioritas Utama), Kuadran I menggambarkan variabel-variabel yang dianggap penting oleh pelanggan, tetapi perusahaan belum melaksanakannya dengan baik.

2) Kuadran II (Pertahankan Prestasi), Kuadran II menunjukkan variabel-variabel yang dianggap penting oleh pelanggan dan telah dilaksanakan dengan baik oleh perusahaan, sehingga pelanggan merasa puas.

3) Kuadran III (Prioritas Rendah), Kuadran III menunjukkan bahwa variabel-variabel yang bersangkutan memang dianggap kurang penting oleh pelanggan sehingga pelaksanaannya juga kurang diperhatikan oleh perusahaan.

4) Kuadran IV (Berlebihan), Kuadran IV menunjukan variabel-variabel yang dianggap kurang penting oleh pelanggan tetapi perusahaan telah menjalankannya dengan sangat baik atau memuaskan sehingga pelanggan menilai kinerja perusahaan terlalu berlebihan.

Selanjutnya untuk mengukur tingkat kepuasaan kosumen terhadap tembakau rakyat "kasturi" dilakukan dengan menggunakan uji Consumer Satisfaction Index (CSI), terdiri dari empat tahapan perhitungan antara lain :

1. Menentukan skor rata-rata tingkat kepentingan atribut atau Mean importance Score (MIS), dan skor rata-rata tingkat kinerja atribut atau Mean Satisfaction Score (MSS) berasal dari rata-rata nilai kepentingan dan kinerja tiap responden. dengan rumus sebagai berikut:

$M I S=\frac{\sum_{i=1}^{n} Y i}{n}$ dan $M S S=\frac{\sum_{i=1}^{n} X i}{n}$

Keterangan:

$\mathrm{N}$ : Jumlah responden

$\mathrm{Xi}$ : Nilai kinerja variabel $\mathrm{X}$ ke-i

Rusiani, L., Tajidan, dan Rosmilawati. 
Yi : Nilai kepetingan variabel Y ke-i

2. Menghitung Weight Factors (WF). Bobot ini merupakan persentase nilai mean importance score (MIS) per atribut terhadap total mean importance score (MPS) seluruh atribut.

$W F=\frac{M I S_{i}}{\sum_{i=1}^{p} M I S_{i}} \times 100 \%$

Keterangan:

$\mathrm{P} \quad$ : Atribut kepentingan ke-p

3. Menghitung Weight Score (WS). Bobot ini merupakan perkalian antara WF dengan rata-rata tingkat kepentingan (MSS).

$\mathrm{WS}=\mathrm{WF} \times \mathrm{MSS}$

4. Menghitung Customer Satisfaction Index (CSI), yaitu weigth score dibagi skala maksimal yang digunakan (dalam penelitian ini skala maksimal 4), kemudian dikalikan 100 persen.

$C S I=\frac{\sum_{i=1}^{p} W S}{4} \times 100 \%$

Kepuasan tertinggi akan tercapai apabila Customer Satisfaction Index (CSI) bernilai $100 \%$. Hal pertama yang dilakukan untuk membuat skala linier numerik adalah mencari rentang skala (RS).

$R S=\frac{m-n}{b}$

Keterangan:

RS : Rentang skala

$\mathrm{m}$ : Skor tertinggi

$\mathrm{n} \quad$ : Skor terendah

b : Jumlah kelas atau kategori yang akan dibuat (dalam penelitian ini digunakan skala maksimal 4).

$R S=\frac{100 \%-0 \%}{4}=25 \%$

Berdasarkan perhitungan di atas, didapatkan rentang skala pengukuran kepuasan pelanggan sebagai berikut:

Tabel 1. Rentang Skala Pengukuran Kepuasan Pelanggan

\begin{tabular}{cc}
\hline Angka Indeks & Interpretasi \\
\hline $75 \%<\mathrm{CSI} \leq 100 \%$ & Sangat Puas \\
$50 \%<\mathrm{CSI} \leq 75 \%$ & Puas \\
$25 \%<\mathrm{CSI} \leq 50 \%$ & Tidak Puas \\
$0 \%<\mathrm{CSI} \leq 25 \%$ & Sangat Tidak Puas \\
\hline
\end{tabular}

Sumber: Simamora dalam Puspadini (2019)

\section{HASIL DAN PEMBAHASAN}

\section{Karakteristik Responden}

Karakteristik umum responden pada penelitian ini dibedakan berdasarkan usia, pendidikan terakhir atau pendidikan yang sedang ditempuh, status pernikahan, pekerjaan, rata-rata pengeluaran per bulan, dan rata-rata pengeluaran untuk rokok per bulan.

Rusiani, L., Tajidan, dan Rosmilawati. 
Tabel 2. Sebaran Karakteristik Responden Tembakau Rakyat "Kasturi"

\begin{tabular}{|c|c|c|c|}
\hline & Karakteristik & $\begin{array}{c}\text { Jumlah responden } \\
\text { (orang) }\end{array}$ & $\begin{array}{c}\text { Presentase } \\
(\%)\end{array}$ \\
\hline & $17-26$ & 22 & 31,43 \\
\hline & $27-36$ & 23 & 32,86 \\
\hline Usia & $37-46$ & 5 & 7,14 \\
\hline & $47-56$ & 11 & 15,71 \\
\hline & $>56$ & 9 & 12,86 \\
\hline & Menikah & 48 & 68,57 \\
\hline Status Pernikahan & Belum Menikah & 21 & 30 \\
\hline & Duda & 1 & 1,43 \\
\hline & Pelajar/Mahasiswa & 5 & 7,14 \\
\hline & Pegawai Negeri & 1 & 1,43 \\
\hline & Karyawan Swasta & 12 & 17,14 \\
\hline Pekerjaan Utama & Wirausaha & 22 & 31,43 \\
\hline & Petani/peternak & 17 & 24,29 \\
\hline & Lainnya & 13 & 18,57 \\
\hline & Tidak Tamat SD & 12 & 17,14 \\
\hline & $\mathrm{SD} / \mathrm{MI}$ & 8 & 11,43 \\
\hline Pendidikan & SMP/MTS & 13 & 18,57 \\
\hline Terakhir & SMA/MA & 24 & 34,29 \\
\hline & D1/D3 & 2 & 2,86 \\
\hline & $\mathrm{S} 1 / \mathrm{S} 2 / \mathrm{S} 3$ & 11 & 15,71 \\
\hline & Kurang dari Rp. 500.000 & 13 & 18,57 \\
\hline & Rp. 500.000-Rp. 999.999 & 10 & 14,29 \\
\hline $\begin{array}{l}\text { Kata-Kata } \\
\text { Pengeluaran Per }\end{array}$ & Rp. 1.000.000-Rp. 1.499 .999 & 22 & 31,43 \\
\hline $\begin{array}{l}\text { Pengeruaran Per } \\
\text { Bulan }\end{array}$ & Rp. 1.500.000-Rp. 1.999 .999 & 13 & 18,57 \\
\hline & Rp. 2.000.000-Rp. 2.500 .000 & 11 & 15,71 \\
\hline & Lebih dari Rp. 2.500 .000 & 1 & 1,43 \\
\hline & Kurang dari Rp. 100.000 & 23 & 32,86 \\
\hline & Rp. 100.000-Rp. 199.999 & 12 & 17,14 \\
\hline Penoeluaran Untuk & Rp. 200.000-Rp. 299.999 & 9 & 12,86 \\
\hline Pengeruaran Untuk & Rp. 300.000-Rp. 399.999 & 8 & 11,43 \\
\hline Rokok Per Bulan & Rp. 400.000-Rp. 450.000 & 5 & 7,14 \\
\hline & Lebih dari Rp. 500.000 & 13 & 18,57 \\
\hline
\end{tabular}

Sumber: Data Primer Diolah (2021)

Berdasarkan tabel karakteristik responden di atas dapat diketahui bahwa usia responden peminat tembakau rakyat "kasturi" terbanyak pada kisaran usia 27-36 sebanyak 23 orang $(32,86 \%)$, status pernikahan terbanyak yaitu menikah sebanyak 48 orang $(68,57 \%)$, pekerjaan utama responden terbanyak pada wirausaha yaitu sebanyak 22 orang $(31,43 \%)$, tingkat pendidikan responden terbanyak pada tingkat SMA/MA yaitu sebanyak 24 orang $(34,29 \%)$, rata-rata pengeluaran per bulan responden terbanyak pada kisaran Rp. 1.000.000-Rp. 1.499 .999 yaitu sebanyak 22 orang $(31,43 \%)$, dan ratarata pengeluaran untuk rokok per bulan responden terbanyak pada kisaran kurang dari Rp. 100.000 yaitu sebanyak 23 orang $(32,86 \%)$. 


\section{Rekomendasi terhadap tembakau rakyat "kasturi"}

Rekomendasi konsumen terhadap produk yang pernah dikonsumsinya kepada calon konsumen bisa menjadi peluang yang besar untuk distributor tembakau rakyat "kasturi". Hal tersebut menjadi salah satu tekhnik promosi yang ideal dikarenakan tidak mengeluarkan biaya sama sekali. Oleh sebab itu perusahaan maupun distributor tembakau rakyat "kasturi" sebisa mungkin terus meningkatkan kualitas produk, sehingga para konsumen merasa puas dan merekomendasikan tembakau rakyat "kasturi" kepada calon konsumen. Dari 70 responden yang ada di Kecamatan Pringgasela sebagian besar konsumen yaitu sebanyak 24 responden merekomendasikan tembakau rakyat "kasturi" kepada calon konsumen yang lain. Untuk lebih jelasnya dapat dilihat pada tabel 3 berikut.

Tabel 3. Rekomendasi Terhadap Tembakau Rakyat "Kasturi"

\begin{tabular}{clc}
\hline No & \multicolumn{1}{c}{ Tingkat Rekomendasi } & Jumlah Responden \\
\hline 1 & Sangat merekomendasikan & 23 \\
2 & Merekomendasikan & 24 \\
3 & Antara merekomendasikan atau tidak & 19 \\
4 & Tidak merekomendasikan & 3 \\
5 & Sangat tidak merekomendasikan & 1 \\
\hline
\end{tabular}

Sumber: data primer diolah (2021)

\section{Atribut-Atribut Tembakau Rakyat "Kasturi" yang Menentukan Kepuasan Konsumen}

Untuk mengukur atribut-atribut tembakau rakyat "kastiri" yang menentukan kepuasan konsumen pada penelitian ini menggunakan metode Importance and Performance Analysis (IPA). Dalam metode Importance Performance Analysis (IPA) ini, kemudian dilakukan perhitungan selanjutnya yaitu perhitungan nilai tingkat kepentingan / harapan dan tingkat kepuasan pelanggan/konsumen tembakau rakyat "kasturi". Kemudian menghitung rata-rata tingkat kepuasan $(\mathrm{X})$ dan rata-rata tingkat kepentingan (Y) dan kemudian hasilnya akan dipetakan ke dalam diagram kartesius yang terbagi dalam 4 kuadran dengan menggunakan bantuan software SPSS 16.0 for Windows.

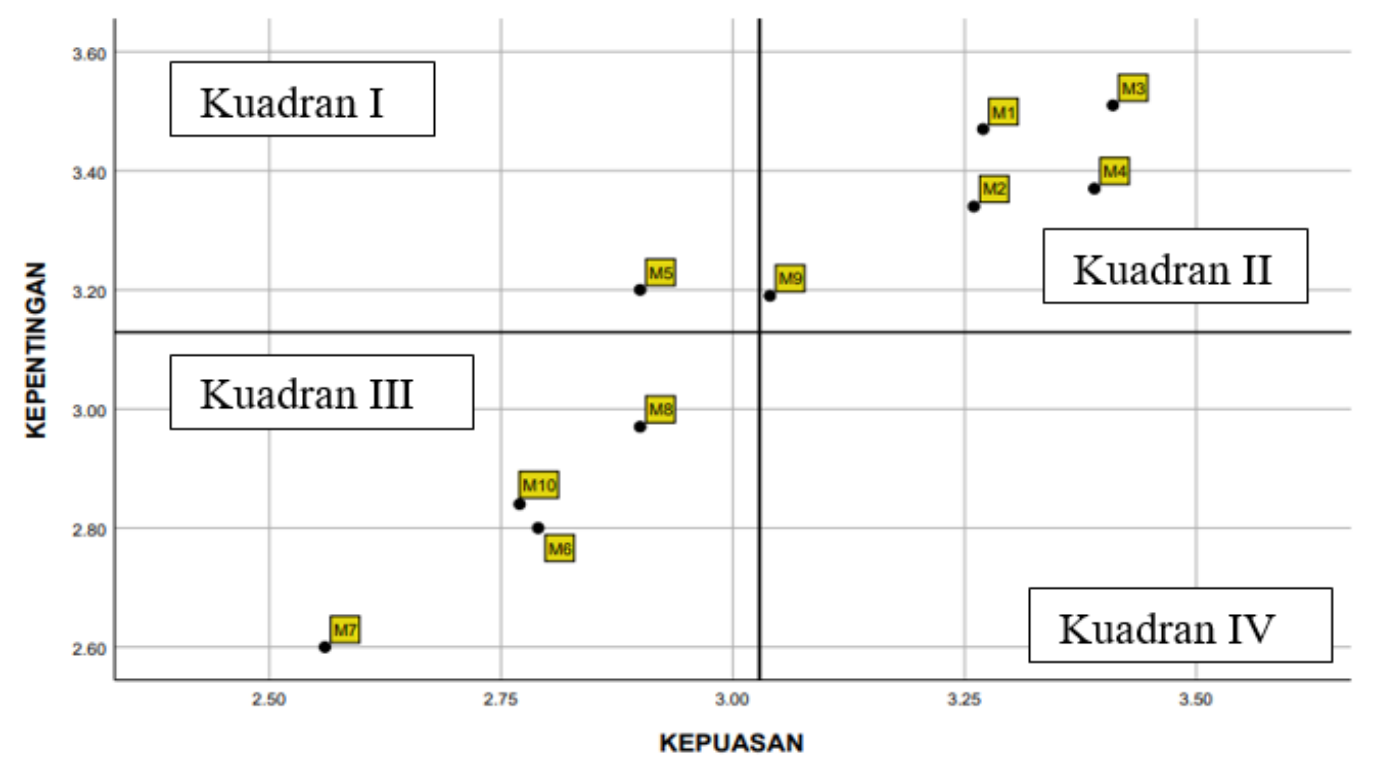

Gambar 2. Diagram Kartesius IPA

Rusiani, L., Tajidan, dan Rosmilawati. 


\section{a. Kuadran I}

Kuadran I adalah prioritas utama dimana atribut yang di plotting ke dalam kuadran ini harus mendapatkan perhatian lebih atau harus diperbaiki. Hal tersebut menunjukkan bahwa konsumen merasakan ketidakpuasan terhadap atribut atau dimensi layanan yang telah diberikan, sehingga perlu adanya perbaikan. Dari diagram di atas dapat dilihat bahwa atribut yang terdapat pada diagram I adalah atribut pertanyaan nomor 5 yaitu "Harga diskon dari penjual tembakau rakyat 'kasturi'". Ternyata hasil dari analisis bertolak belakang dengan latar belakang yang telah dikemukakan. Diduga hal tersebut terjadi karena konsumen memilih tembakau rakyat "kasturi" dikarenakan harga yang murah apabila dibandingkan dengan harga rokok putih. Namun, harga sebenarnya dari tembakau rakyat "kasturi" belum memuaskan konsumen sehingga konsumen masih mengharapkan adanya diskon dari perusahan ataupun distributor tembakau rakyat "kasturi". Untuk meningkatkan pangsa pasar produk dengan membuat pelanggan berkeinginan dalam membeli produk lebih banyak dari biasanya dengan promosi penjualan melalui pemberian promosi penjualan ekstensif, misalnya dengan menambahkan bonus produk untuk pembelian dalam jumlah yang banyak (Dananjaya, et al., 2019). Sebaiknya dari pihak perusahaan melakukan peningkatan pada atribut yang ada pada kuadran ini supaya konsumen tembakau rakyat "kasturi" bisa merasa puas di masa mendatang. Kegiatan promosi dapat memperkenalkan, mempengaruhi dan menarik konsumen secara langsung terhadap produk yang dihasilkan (Suparyana, et al., 2020).

b. Kuadran II

Kuadran II adalah "pertahankan prestasi" dimana memiliki tingkat skor yang paling tinggi baik dari segi tingkat kepentingan konsumen dan tingkat kinerjanya, sehingga atribut yang berada pada kuadran II dapat dikatakan aman dan harus dipertahankan kinerjanya. Atribut yang di plotting ke dalam kuadran ini antara lain atribut pertanyaan nomor 1, 2, 3, 4 dan 9 yang lebih jelasnya dapat dilihat pada tabel 4 . Produk yang berkualitas dapat dilihat dari beberapa indikator salah satunya performance produk tersebut (cita rasa, tekstur, aroma) yang dapat memberikan kepuasan konsumen (Sukanteri, et al., 2020). Khusus atribut nomor 9 "mengkonsumsi tembakau rakyat 'kasturi' yang dapat meningkatkan kepercayaan diri" terlihat bertolak belakang dengan latar belakang yang menyatakan bahwa konsumen tembakau rakyat "kasturi" akan tetap memilih rokok putih jika pendapatan lebih stabil. Namun hasil penelitian menunjukkan konsumen percaya diri dengan mengkonsumsi tembakau rakyat. Hal tersebut terjadi karena level percaya diri konsumen dalam mengkonsumsi rokok putih lebih tinggi daripada mengkonsumsi tembakau rakyat. Artinya bahwa konsumen sudah percaya diri dengan hanya mengkonsumsi tembakau rakyat, akan tetapi konsumen akan lebih percaya diri lagi jika mengkonsumsi rokok putih.

Tabel 4. Atribut-Atribut Kuadran II

\begin{tabular}{ccc}
\hline No & Atribut & Dimensi \\
\hline 1 & Cita rasa dari tembakau rakyat "kasturi" & Produk (Product) \\
2 & Tekstur/ukuran rajangan dari tembakau rakyat "kasturi" & Produk (Product) \\
3 & Aroma dari tembakau rakyat "kasturi" & Produk (Product) \\
4 & Harga tembakau rakyat "kasturi" yang sesuai dengan kualitas & Harga (Price) \\
9 & Mengkonsumsi tembakau rakyat "kasturi" yang dapat & Performansi \\
& meningkatkan kepercayaan diri. & (Performance) \\
\hline
\end{tabular}

Sumber: data primer diolah (2021)

Rusiani, L., Tajidan, dan Rosmilawati. 


\section{c. Kuadran III}

Kuadran III adalah "Prioritas Rendah", dimana atribut ini dianggap kurang penting pengaruhnya bagi pelanggan dan pada kenyataannya kinerjanya tidak terlalu istimewa. Bagi pihak distributor tembakau rakyat "kasturi" sebaiknya perlu dipertimbangkan lagi pada atribut ini karena atribut yang masuk pada kuadran ini dianggap kurang penting dan kurang memuaskan bagi konsumen. Atribut yang di plotting ke dalam kuadran ini antara lain atribut pertanyaan nomor $6,7,8$, dan 10 yang lebih jelasnya dapat dilihat pada tabel 5 berikut.

Tabel 5. Atribut-Atribut Kuadran III

\begin{tabular}{clc}
\hline No & \multicolumn{1}{c}{ Atribut } & Dimensi \\
\hline 6 & $\begin{array}{l}\text { Desain kemasan tembakau rakyat "kasturi" yang } \\
\text { menarik. }\end{array}$ & Kemasan \\
7 & $\begin{array}{l}\text { Inovasi kemasan (kemasan yang trendi) dari } \\
\text { tembakau rakyat "kasturi". }\end{array}$ & Kemasan \\
8 & $\begin{array}{l}\text { Kemudahan dalam menyimpan tembakau rakyat } \\
\text { "kasturi". }\end{array}$ & Kemaging) \\
10 & Efek ketergantungan dari tembakau rakyat "kasturi”. & (Packaging) \\
\end{tabular}

Sumber: data primer diolah (2021)

\section{d. Kuadran IV}

Kuadran IV adalah "Berlebihan", ini menunjukkan bahwa atribut pada kuadran ini dinilai memiliki tingkat kepentingan yang rendah namun tingkat kinerja yang diberikan tinggi. Dianggap kurang penting tetapi kinerja yang diberikan sangat memuaskan konsumen tembakau rakyat "kasturi". Dari gambar 2 di atas dapat dilihat bahwa tidak ada atribut tembakau rakyat "kasturi" yang di plotting kuadran ini. Hal ini berarti bahwa atribut-atribut yang ada pada tembakau rakyat "kasturi" tidak ada yang dianggap berlebihan oleh konsumen.

\section{Atribut-Atribut Tembakau Rakyat "Kasturi” Yang Perlu Untuk Diperbaiki Guna Meningkatkan Kepuasan Konsumen}

Untuk mengukur atribut-atribut tembakau rakyat "kastiri" yang menentukan kepuasan konsumen pada penelitian ini menggunakan matode Importance and Performance Analysis (IPA). Dalam metode Importance Performance Analysis (IPA) ini, kemudian dilakukan perhitungan selanjutnya yaitu perhitungan nilai tingkat kepentingan / harapan dan tingkat kepuasan pelanggan / konsumen tembakau rakyat "kasturi" . Kemudian menghitung rata-rata tingkat kepuasan $(\mathrm{X})$ dan rata-rata tingkat kepentingan (Y) dan kemudian hasilnya akan dipetakan ke dalam diagram kartesius yang terbagi dalam 4 kuadran dengan menggunakan bantuan software SPSS 16.0 for Windows.

Berdasarkan analisis data yang telah dijelasakan pada butir 4.4 di atas dapat diketahui bahwa atribut-atribut tembakau rakyat "kasturi" yang perlu untuk diperbaiki guna meningkatkan kepusan konsumen di masa mendatang berada pada kuadran I (Prioritas Utama) yaitu atribut nomor 5 "Harga diskon dari penjual tembakau rakyat "kasturi" dan pada kuadran III yang terdiri dari atribut nomor 6 "Desain kemasan tembakau rakyat 'kasturi' yang menarik", atribut nomor 7 "Inovasi kemasan (kemasan yang trendi) dari tembakau rakyat "kasturi'", atribut nomor 8 "Kemudahan dalam meyimpan tembakau rakyat 'kasturi'", dan atribut nomor 9 "Efek ketergantungan dari tembakau rakyat 'kasturi'". Hal tersebut disebabkan karena atribut produk yang berada pada kuadran I merupakan atribut yang sangat penting dalam menentukan kepuasan 
konsumen terhadap tembakau rakyat "kasturi", namun dari pihak perusahaan ataupun distributor belum memberikan kinerja yang maksimal terhadap atribut tersebut. Sedangkan atribut produk yang berada pada kuadran III merupakan atribut yang tidak terlalu penting dalam menentukan kepuasan konsumen tembakau rakyat "kasturi". Oleh sebab itu pihak perusahaan ataupun distributor tembakau rakyat "kasturi" sebaiknya mempertimbangkan lagi atribut yang ada pada kuadran ini.

\section{Tingkat Kepuasan Konsumen Terhadap Atribut Kualitas Tembakau Rakyat "Kasturi"}

Analisis kepuasan konsumen secara keseluruhan dilakukan dengan menghitung nilai Customer Satisfaction Index (CSI). Nilai CSI diperoleh dengan membagi Weighted Average (Penjumlahan seluruh Weighted Score) dengan skala maksimum (skala lima) yang digunakan dalam penelitian ini. Skala kepuasan konsumen yang umum dipakai dalam interprestasi indeks adalah skala 0 sampai skala 1.

Berdasarkan dari hitungan indeks kepuasan pelanggan, nilai CSI tembakau rakyat "kasturi" mendapatkan skor sebesar 76,34 \% yang berada pada rentang 75-100\% yang dilihat berdasarkan kinerja dan kepentingan atirbut-atribut berada pada kriteria sangat puas. Meskipun demikian dengan berkembangnya banyaknya perusahaan rokok, maka dari itu dari pihak pengusaha tembakau rakyat "kasturi" harus bisa meningkatkan kinerja produknya pada taraf sangat puas yang diindikasikan dengan nilai CSI yang mendekati angka $100 \%$ itu akan jauh lebih baik, dimana pelanggan benar-benar merasakan kinerja atribut-atribut dari pengusaha tembakau rakyat "kasturi" sama dengan tingkat kepentingan yang mereka tetapkan.

Tabel 6. Uji Customer Satisfaction Index (CSI)

\begin{tabular}{|c|c|c|c|c|c|}
\hline No & Atribut & MIS & WF & MSS & WS \\
\hline 1 & Cita rasa dari tembakau rakyat "kasturi". & 3,47 & 11,09 & 3,27 & 33,11 \\
\hline 2 & $\begin{array}{l}\text { Tekstur/ukuran rajangan dari tembakau } \\
\text { tembakau rakyat "kasturi". }\end{array}$ & 3,34 & 10,68 & 3,26 & 31,74 \\
\hline 3 & Aroma dari tembakau rakyat "kasturi". & 3,51 & 11,23 & 3,41 & 34,98 \\
\hline 4 & $\begin{array}{l}\text { Harga tembakau rakyat "kasturi" yang } \\
\text { sesuai dengan kualitas. }\end{array}$ & 3,37 & 10,77 & 3,39 & 33,28 \\
\hline 5 & $\begin{array}{l}\text { Harga diskon dari penjual tembakau } \\
\text { rakyat "kasturi". }\end{array}$ & 3,20 & 10,22 & 2,90 & 27,06 \\
\hline 6 & $\begin{array}{l}\text { Desain kemasan tembakau rakyat } \\
\text { "kasturi" yang menarik. }\end{array}$ & 2,80 & 8,59 & 2,79 & 22,74 \\
\hline 7 & $\begin{array}{l}\text { Inovasi kemasan (kemasan yang trendi) } \\
\text { dari tembakau rakyat "kasturi". }\end{array}$ & 2,60 & 8,31 & 2,56 & 19,38 \\
\hline 8 & $\begin{array}{l}\text { Kemudahan dalam menyimpan tembakau } \\
\text { rakyat "kasturi". }\end{array}$ & 2,97 & 9,49 & 2,90 & 25,12 \\
\hline 9 & $\begin{array}{l}\text { Mengkonsumsi tembakau rakyat "kasturi" } \\
\text { yang dapat meningkatkan kepercayaan } \\
\text { diri. }\end{array}$ & 3,19 & 10,18 & 3,04 & 28,26 \\
\hline 10 & $\begin{array}{l}\text { Efek ketergantungan dari tembakau } \\
\text { rakyat "kasturi". }\end{array}$ & 2,84 & 9,08 & 2,77 & 22,97 \\
\hline & Jumlah & 31,30 & 100 & 30,29 & 305,36 \\
\hline & CSI & \multicolumn{4}{|c|}{$76,34 \%$} \\
\hline
\end{tabular}

Sumber: data primer diolah (2021) 


\section{KESIMPULAN DAN SARAN}

\section{Kesimpulan}

Dari pembahasan di atas maka dapat diambil kesimpulan sebagai berikut:

a. Atribut-atribut produk yang menentukan kepuasan konsumen terdapat pada kuadran II (Pertahankan Prestasi) meliputi 5 atribut diantaranya, 1) Cita rasa dari tembakau rakyat "kasturi", 2) Tekstur/ukuran rajangan dari tembakau tembakau rakyat "kasturi", 3) Aroma dari tembakau rakyat "kasturi", 4) Harga tembakau rakyat "kasturi" yang sesuai dengan kualitas, dan 5) Mengkonsumsi tembakau rakyat "kasturi" yang dapat meningkatkan kepercayaan diri. Hal ini dikarenakan 5 atribut produk dianggap memiliki kinerja yang tinggi dan sangat menentukan kepuasan konsumen.

b. Atribut-atribut produk yang perlu untuk diperbaiki guna meningkatkan kepuasan konsumen tembakau rakyat "kasturi" terdapat pada kuadran I dan III (Priotitas Rendah) meliputi 5 atribut antara lain, 1). Harga diskon dari penjual tembakau rakyat "kasturi", 2.) Desain kemasan tembakau rakyat "kasturi" yang menarik, 3). Inovasi kemasan (kemasan yang trendi) dari tembakau rakyat "kasturi", 4). Kemudahan dalam menyimpan tembakau rakyat "kasturi", dan 5). Efek ketergantungan dari tembakau rakyat "kasturi". Hal ini dikarenakan 1 atribut produk dianggap sangat penting oleh konsumen dan memiliki kinerja yang sangat bagus dalam menentukan kepuasan konsumen akan tetapi perusahaan maupun distributor tidak mengerjakannya dengan maksimal dan 4 atribut tidak terlalu penting dan memiliki kinerja yang kurang bagus dalam menentukan kepuasan konsumen.

c. Tingkat kepuasan konsumen terhadap tembakau rakyat "kasturi" di Kecamatan Pringgasela menunjukkan bahwa secara keseluruhan konsumen merasa sangat puas terhadap tembakau rakyat "kasturi", hal ini dapat dilihat dari nilai Customer Satisfaction Index (CSI) sebesar 76,34\% dengan rentang skala 75-100\%.

\section{Saran}

Berdasarkan pada hasil penelitian, maka dapat peneliti kemukakan beberapa saran yaitu sebagai berikut:

a. Tetap mempertahankan atribut-atribut yang dianggap sudah memuaskan konsumen sehingga perusahaan ataupun distributor tembakau rakyat "kasturi" akan lebih fokus untuk meningkatkan kualitas produk yang dianggap kurang.

b. Meningkatkan atribut-atribut yang sangat penting bagi konsumen seperti "diskon dari penjual". Hal ini bisa dilakukan dengan memberikan bonus kertas rokok dan korek api setiap beberap kali dalam setahun, sehingga loyalitas konsumen dapat diciptakan dan perusahaan juga tidak mengalami kerugian.

c. Dikarenakan adanya kelemahan pada peneliti dalam melakukan penelitian ini, sehingga tidak dapat mewakili teori secara keseluruhan. Untuk itu disarankan kepada peneliti selanjutnya yang tertarik meneliti kepuasan konsumen untuk dapat melakukan penelitian di perusahaan yang independen sehingga dapat membandingkan hasil peneliian dengan sebelumnya. 


\section{DAFTAR PUSTAKA}

BPS Nusa Tenggara Barat. (2020). Nusa Tenggara Barat Dalam Angka 2020. Badan Pusat Statistik NTB: Mataram.

Dananjaya, I. G. A. N., Suparyana, P. K., Setiawan, I. M. D., \& Yuniti, I. G. A. D. Strategi Pengembangan Kegiatan Ekonomi Kreatif PKK di Kota Tabanan terhadap Peningkatan Pendapatan Anggota. JIA (Jurnal Ilmiah Agribisnis): Jurnal Agribisnis dan Ilmu Sosial Ekonomi Pertanian, 5(6), 207-221.

Nursan, M., Ayu, C., \& Suparyana, P. K. (2020). Analisis Keuntungan dan Kelayakan Ekonomi Usahatani Tembakau Virginia di Kabupaten Lombok Tengah. Jurnal Ilmiah Membangun Desa dan Pertanian (JIMDP), 5(3), 104-110.

Priagus, A. (2019). Analisis Kepuasan Konsumen "Angkringan Kampus" Kecamatan Dramaga, Kabupaten Bogor [Skripsi]. Bogor: Institut Pertanian Bogor.

Puspadini, T. A. (2019). Analisis Kepuasan Pelanggan Maraca Books \& Coffee 2 [Skripsi]. Bogor: Institut Pertanian Bogor.

Rachmat, M. (2010). Pengembangan Ekonomi Tembakau Nasional: Kebijakan Negara Maju Dan Pembelajaran Bagi Indonesia. Analisis Kebijakan Pertanian. 8(1), 6783.

Santoso, I., Mulyarto, A., \& Maharani, S. (2012). Consumer Perception on Quality of Bakpao Telo with Importance - Performance Analysis Method. Jurnal Teknologi Pertanian. 12(1).

https://jtp.ub.ac.id/index.php/jtp/article/view/330

Sukanteri, N. P., Suparyana, P. K., Suryana, I. M., Yuniti, D., \& Verawati, Y. (2020). Manajemen Pengendalian Mutu Dalam Produksi Agribisnis pada Kelompok Wanita Tani Ayu Tangkas. JURNAL GALUNG TROPIKA. 9(3), 209-222.

Suparyana, P. K., Nabilah, S., \& Sukanteri, N. P. (2020). Faktor Internal Eksternal Dalam Bauran Pemasaran Produk Ukm Kopi Dadong. dwijenAGRO. 10(2), 109116.

Wilujeng, E. (2013). Analisis Efisiensi Penggunaan Faktor Produksi Dalam Upaya Peningkatan Pendapatan Petani Tembakau Besuki Na Oogst [Skripsi]. Jember: Universitas Jember. 